\title{
Inferior Pancreaticoduodenal
}

\section{Artery Aneurysm Associated with Obstruction of the Celiac Trunk and Cancer of the Head of the Pancreas}

\begin{abstract}
Aneurysm of the visceral arteries is a rare condition and it represents around $1 \%$ of all arterial aneurisms. Aneurysm of the inferior pancreaticoduodenal artery represents around $2 \%$ of all visceral aneurysms. Aneurysm associated with occlusion of the coeliac trunk is very rare condition and there are only about 40 cases presented in the literature. In our study, we presented 56 year-old female admitted to hospital with obstructive jaundice. CT scan diagnosed tumor of the head of pancreas and CT angiography confirmed aneurysm of the inferior pancreaticoduodenal artery which was successfully operated at our clinic.
\end{abstract}

Keywords: pancreaticoduodenal artery aneurysm, cancer of the head of pancreas, obstruction of celiac trunk

DOI: $10.7251 /$ SMDEN1501073C

(Scr Med 2015:46:73-75)

\section{Jovan Ćulum', Darko Golić², Aleksandar Guzijan', Darko Jović ${ }^{4}$, Branislava Jakovljević ${ }^{4}$, Aleksandar Jakovljević ${ }^{4}$, Davor Grahovac ${ }^{3}$}

\section{${ }^{1}$ Clinic for General and Abdominal Surgery, University hospital Clinical center Banjaluka \\ 2 Clinic for Anesthesiology, Universi- ty hospital Clinical center Banjaluka 3 Clinic for Oncology, University hospital Clinical center Banjaluka 4 Clinic "Stetik" Banjaluka}

\author{
Contact address: \\ Jovan Ćulum \\ Jovan Ćulum \\ Ul.Braće Čubrilović $10 a$ \\ Banja Luka \\ Tel-065 580 o88 \\ e-mail-culumj61@gmail.com
}

Submitted: November 3th, 2014 Accepted: December 22nd, 2014

\section{Case report}

A 56 year-old female with obstructive jaundice was admitted at our clinic. US and CT scan confirmed the tumor of the head of pancreas and CT angiography diagnosed aneurysm of the inferior pancreaticoduodenal artery with obstruction of celiac artery. (Figure 1.).

Figure 1. CT angiography aneurysm of the inferior pancreaticoduodenal artery

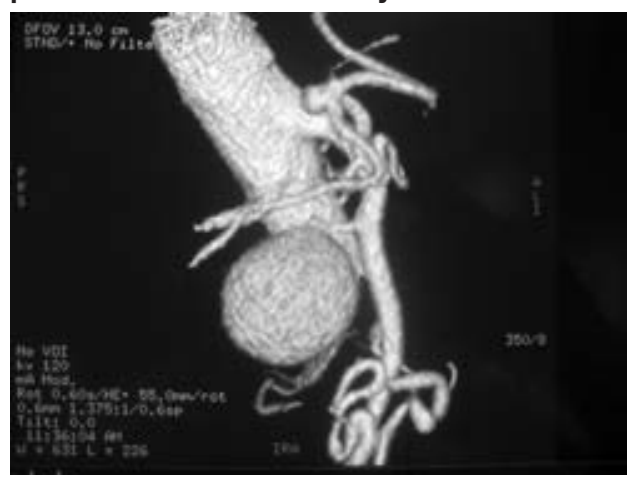

Painless jaundice was the cause of doctor's appointment and aneurysm of the pancreaticoduodenal artery was discovered accidentally, as it was asymptomatic.

With the usage of upper median laparotomy, we opened the abdominal cavity, removed tumor together with the head of the pancreas, duodenum and gastric antrum. By careful preparation we showed aneurysms of the artery pancreaticoduodenal, which was ligated and resected at the origin of the upper mesenteric artery (Figure 2.). Upon the resection, we tested a sufficiency of the collateral circulation (Figure 2.). As surgery lasted for about 5 hours and there were no signs of ischemia of the liver, spleen and stomach stump, there was no need for revascularization of the celiac trunk.

Biliodigestive reconstruction and reconstruction of the digestive tract was performed according to standard Whipple method. The postoperative course was satisfactory. Subsequent histological analysis confirmed adenocarcinoma of the pancreatic head. 
Figure 2. Aneurysms of the artery pancreaticoduodenal

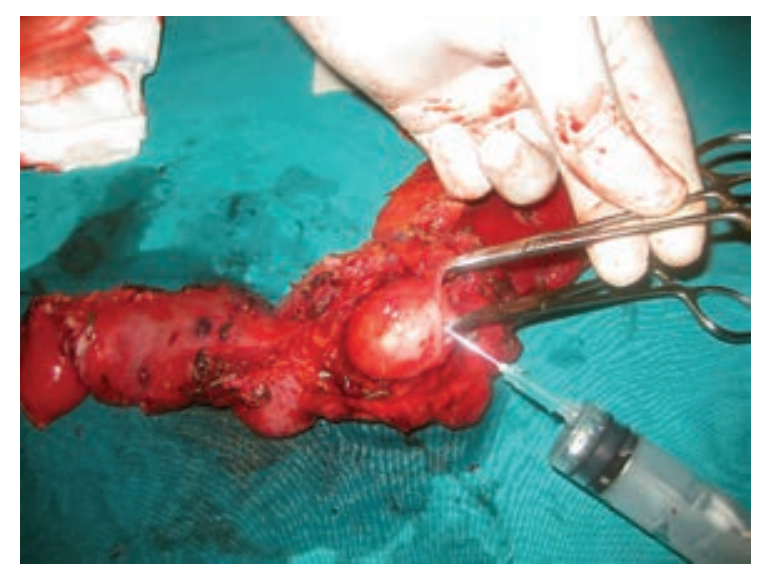

\section{Discussion}

Aneurysms of visceral arteries are very rare but lifethreatening states. They present only about $1-2 \%$ of all aneurysms, and pancreaticoduodenal artery is a very rare place for the aneurysm occurrence. Only about 40 cases of aneurysms of the pancreaticoduodenal arteries associated with thrombosis or occlusion of the celiac trunk has been reported in the literature. ${ }^{1}$ That state is not considered to be particularly coincidental, because by the occlusion of the main celiac, a liver, spleen and stomach are vascularized through the upper mesenteric artery across the pancreaticoduodenal arcade. Chronically hypertension leads to weakness of the arterial wall, and causes dilation and aneurysm formation. Aneurysm can be associated with the development of abundant collateral circulation. ${ }^{2,3}$ The aneurysm itself is asymptomatic at first, then with nonspecific abdominal symptoms, and may lead to rupture and potentially life-threatening intraabdominal hemorrhage. Less asymptomatic aneurysm incidentally detected by CT examination. Some patients may have signs of mesenteric ischemia due to stenosis or associated extraluminal compression of mesenteric artery. Rupture of an aneurysm in the retropertoneal space is a severe condition that is manifested by severe abdominal pain, and may be developed and hypovolemic shock if the rupture at the free abdominal cavity. Extremely rare is rupture of the digestive tract (stomach, duodenum, small and large intestine). The incidence of rupture is not directly proportional to the size of the aneurysm and it is difficult to predict the potential risk of rupture. Therefore, it is necessary to treat all types of diagnosed aneurisms., ${ }^{2,3}$

When conventional selective angiography or CT angiography diagnoses visceral artery aneurysms, it is necessery to preform a dynamic evaluation of collateral blood flow and diagnose the possible obstruction of the main splanhnich artery. CT angiography isa more recent and very successful non-invasive method to achieve an accurate diagnosis. Two-and three-dimensional video clearly shows the localization of the aneurysm and possible visceral artery stenosis. Endovascular stenting of the occluded visceral arteries and transcatheter embolization of aneurysms are the best option treatment for diagnosing the asymptomatic aneurysms. Transcateter embolization is the method of interventional radiology which can have complications (aneurysm rupture, intestinal ischemia, etc.). Surgical treatment involves ligation and resection,and, when possible, a reconstruction. Some authors advocate revascularization of the celiac trunk in the case of poorly developed collateral circulation. ${ }^{4,5}$

\section{Conclusions}

Aneurysms of the pancreaticoduodenal artery with obstruction of coeliac truk are very rare conditions. Correlation with pancreatic carcinoma is coincidental, and surgical treatment is the method of choice due to the basic disease. Radicality of oncological procedure is a specified option and surgical resection of aneurysm is the treatment of choice. It is not necessery to perform reconstruction of pancreaticoduodenal artery because of the conducted and extensive surgical procedure for the malignant disease (cephalic duodenopancreatectomy). Furthermore, due to the well-developed collateral circulation, it is usually not necessary to open the main tree celiac trunk, and the cephalic duodenopancreatectomy itself is used to amputate the irrigation area of pancreaticoduodenal arcades.

\section{References}

1. Takao H, Doi I, Ohtomo K. Natural history of true pancreaticoduodenal artery aneurysms.Br J Radiol. 2010 September; 83(993): 744-746.

2. Hildebrand P, Esnaashari H, Franke C, Bürk C, Bruch H P. Surgical management of pancreaticoduodenal artery aneurysms in association with celiac trunk occlusion or stenosis. Ann Vasc Surg. 2007;21(1):10-15.

3. Kalva SP, Athanasoulis CA, Greenfield AJ, Fan CM, Curvelo M, Waltman AC, et al. Inferior pancreaticoduodenal artery aneurysms in association with coeliac axis stenosis or occlusion. Eur J Vasc Endovasc Surg 2007;33:670-5.

4. Bellosta R, Luzzani L, Carugati C, Melloni C, Sarcina A. Pancreaticoduodenal artery aneurysms associated with celiac axis occlusion. Ann Vasc Surg. 2005;19(4):534-539.

5. Brocker JA, Mehel JL, Smith RW.True pancreaticoduodenal aneurysms with celiac stenosis or occlusion.Am.J.Surg. 2012;204(5):762-8.

6. Flood K, Nicholson AA:Inferior pancreticoduodenal artery aneurysms associated with occusive lesions of the celiac axis:diagnosis, treatment options, outcames and review in the literature.Cardiovasc Intervent Radiol.2013;36(3):578-87 


\section{Aneurizma donje pankreatikoduodenalne arterije udružena sa opstrukcijom celijačnog stabla i karcinomom glave pankreasa}

\section{APSTRAKT}

Sažetak: Aneurizme visceralnih arterija su rijetka stanja i čine oko 1\% svih arterijskih aneurizmi. Aneurizma pankreatikoduodenalne arterije čini svega oko $2 \%$ svih visceralnih aneurizmi. Aneurizma pankreatikoduodenalne arterije povezana s okluzijom celijačnog stabla je vrlo rijetko stanje i samo oko 40-tak slučajeva do sada je opisano u literaturi. Predstavili smo 56 godina staru ženu primljenu u bolnicu zbog opstruktivne žutice, CT-a dijagnostikovanog tumora glave gušterače i CT angiografski dokazane aneurizme donje pankreatikoduodenalne arterije koja je uspješno operisana u našoj klinici.

Ključne riječi: aneurizma pankreatikoduodenalne arterije, karcinom glave gušterače, opstrukcija celijačnog stabla 